\title{
EVALUASI PENGARUH FINANCIAL CONSTRAINTS TERHADAP HUBUNGAN ANTARA WORKING CAPITAL FINANCING DENGAN FIRM PERFORMANCE
}

\author{
Maria Angelica Brigita \\ Program Studi Magister Manajemen Universitas Tarumanagara \\ brigit4angel@gmail.com \\ Indra Widjaja \\ Program Studi Magister Manajemen Universitas Tarumanagara
}

Masuk : 25-11-2020, revisi : 24-12-2020 diterima untuk diterbitkan : 28-12-2020

\begin{abstract}
The purpose of this research is to examine the influence of working capital financing toward firm performance with a moderating effect from financial constraints in consumer goods and mining companies listed in Indonesia Stock Exchange from year 2014 until 2018. The sample was determined by purposive sampling method. The research conducted by taking 40 consumer goods companies and 41 mining companies. This research used Eviews program version 11 and use GMM to process obtained data from the research sample. The result of this research shows that working capital financing has positive and non-linear (inverted u shape) effect on firm performance. This research also shows that financial constraints has positively effect on non-linear relationship between working capital financing and firm performance.
\end{abstract}

Abstrak: Tujuan dari penelitian ini adalah untuk menguji pengaruh dari working capital financing terhadap firm performance dengan efek moderasi dari financial constraints pada perusahaan consumer goods dan mining yang terdaftar di Bursa Efek Indonesia dari tahun 2014 hingga tahun 2018. Sampel penelitian ini ditentukan dengan menggunakan metode purposive sampling. Penelitian ini dilakukan atas 40 perusahaan consumer goods dan 41 perusahaan mining. Penelitian ini menggunakan aplikasi pengolah data Eviews versi 11 dan menggunakan metode $G M M$ untuk mengolah data yang diperoleh dari sampel penelitian. Hasil dari penelitian ini menunjukkan bahwa working capital financing memiliki pengaruh yang positif dan nonlinier (berbentuk huruf $U$ terbalik) terhadap firm performance. Penelitian ini juga menunjukkan bahwa financial constraints memiliki pengaruh yang positif terhadap hubungan non-linier antara working capital financing dan firm performance.

Keywords: Working Capital Financing, Firm Performance, Financial Constraints, GMM

\section{PENDAHULUAN}

Peningkatan investasi dapat mendukung peningkatan perekenomian Indonesia melalui penyerapan tenaga kerja, perluasan lapangan pekerjaan, serta perbaikan infrastruktur. Sektor pertambangan maupun barang konsumsi memberikan kontribusi yang signifikan bagi pertumbuhan perekonomian di Indonesia. Peningkatan daya beli konsumen semakin menciptakan peluang bisnis yang menjanjikan bagi perusahaan-perusahaan sektor barang konsumsi di Indonesia. Oleh sebab itu, setiap perusahaan yang bergerak pada sektor pertambangan maupun barang konsumsi di Indonesia harus senantiasa memberikan kinerja yang terbaik untuk dapat mendorong peningkatan investasi secara signifikan di Indonesia. Manajemen modal kerja merupakan instrumen yang penting bagi perusahaan untuk meraih kinerja terbaiknya. Manajemen modal kerja yang efisien didasarkan pada keputusan pendanaan jangka pendek dengan tetap mempertahankan keseimbangan antara likuiditas dan profitabilitas perusahaan. Kebutuhan untuk memahami kebijakan pembiayaan modal kerja menjadi sangat diperlukan untuk setiap perusahaan, sehingga peneliti tertarik untuk melakukan penelitian ini. 


\section{Tujuan Penelitian}

Penentuan kebijakan pembiayaan modal kerja merupakan suatu perkara yang tidak mudah untuk dilakukan di dalam suatu perusahaan. Kebijakan pembiayaan modal kerja dengan menggunakan proporsi pembiayaan jangka pendek yang lebih kecil dapat mengurangi risiko pembiayaan bagi perusahaan, namun tidak memberikan return yang tinggi bagi perusahaan, Sebaliknya, kebijakan pembiayaan modal kerja dengan menggunakan proporsi pembiayaan jangka pendek yang lebih besar dapat memberikan return yang tinggi bagi perusahaan, namun menyebabkan tingkat risiko yang dihadapi perusahaan menjadi semakin tinggi. Oleh sebab itu, penelitian ini bertujuan untuk membuktikan secara empiris pengaruh Working Capital Financing $(W C F)$ terhadap Firm Performance serta pengaruh WCF terhadap Firm Performance dengan dimoderasi oleh Financial Constraints. Selain itu, penelitian ini juga betujuan untuk membuktikan secara empiris pengaruh variabel-variabel kontrol seperti Firm Size, Growth, Leverage, dan Current Ratio terhadap Firm Performance.

\section{TINJAUAN PUSTAKA}

Menurut konsep Pecking Order Theory dalam kaitannya dengan kebijakan pembiayaan modal kerja, perusahaan yang memiliki efek leverage yang tinggi cenderung memilih pendekatan agresif untuk membiayai modal kerjanya (memperketat kondisi kredit untuk pelanggan dan mengurangi tingkat persediaan). Hal ini cenderung dilakukan perusahaan untuk memastikan pembiayaan dilakukan menggunakan sumber dana internal dan menghindari penerbitan utang maupun ekuitas perusahaan (Bereznicka, 2014:37). Melalui konsep Pecking Order Theory, keputusan pendanaan yang hendak diperoleh dari eksternal perusahaan juga dipandang dari sisi kendala keuangan yang mungkin akan dihadapi oleh perusahaan. Dengan tingkat kendala keuangan tertentu yang dihadapi perusahaan, maka dapat ditentukan sumber pendanaan eksternal yang paling memberikan nilai tambah bagi perusahaan.

Modal kerja merupakan perbedaan atau selisih antara aset lancar dengan kewajiban lancar yang menjadi dasar untuk mengukur tingkat likuiditas keuangan suatu perusahaan (Ding, Guariglia, \& Knight, 2013:1491). Melalui pandangan konservatif, perusahaan melakukan pembiayaan untuk kebutuhan modal kerja dengan menggunakan proporsi utang jangka panjang yang lebih besar dari proporsi utang jangka pendek. Dengan memilih pendekatan konservatif, perusahaan dapat mengurangi risiko bunga dan risiko pembiayaan kembali namun di sisi lain harus menghadapi biaya-biaya yang mungkin dapat timbul karena likuiditas keuangan perusahaan (Altaf \& Ahmad, 2019:464). Sedangkan melalui pandangan agresif, perusahaan melakukan pembiayaan untuk kebutuhan modal kerja dengan menggunakan proporsi utang jangka pendek yang lebih besar dari proporsi utang jangka panjang. Berdasarkan pendapat Baños-Caballero, García-Teruel, dan Martínez-Solano (2016:1190), perusahaan yang memilih menggunakan pendekatan agresif dapat mengurangi biaya keuangan, biaya keagenan antara perusahaan dengan pemegang saham maupun dengan pihak pemberi pinjaman, serta memperoleh kondisi kredit yang lebih menguntungkan karena tingginya frekuensi pembentukan kredit jangka pendek. Namun di lain sisi, perusahaan harus menghadapi biaya-biaya ilikuiditas keuangan perusahaan (Altaf \& Ahmad, 2019:464).

Altaf dan Ahmad (2019:466) berpendapat bahwa ketika proporsi pendanaan jangka pendek yang digunakan untuk membiayai modal kerja perusahaan lebih kecil, kinerja keuangan perusahaan akan semakin meningkat karena manfaat yang diperoleh perusahaan lebih besar jika dibandingkan dengan biaya yang dikeluarkannya sedangkan ketika proporsi pendanaan jangka pendek yang digunakan lebih besar, kinerja keuangan perusahaan dapat menurun karena biaya yang dikeluarkan lebih besar dibandingkan dengan manfaat yang diperoleh. Menurut Panda dan Nanda (2018:444), hal tersebut disebabkan karena tingkat suku bunga atas sumber pendanaan jangka pendek lebih berfluktuatif jika dibandingkan dengan tingkat suku bunga atas sumber pendanaan jangka panjang. Sehingga terdapat hubungan non-linier antara keputusan pembiayaan modal kerja terhadap kinerja perusahaan dimana penggunaan pembiayaan jangka 
pendek sampai dengan batas tertentu dapat meningkatkan kinerja perusahaan (BañosCaballero, García-Teruel, dan Martínez-Solano, 2016:1197).

Kendala keuangan atau Financial Constraints dapat didefinisikan sebagai suatu kondisi dimana perusahaan memiliki kemampuan menghasilkan uang yang terbatas sehingga dapat menyebabkan perusahaan mengurangi investasinya atas modal kerja, mempercepat penagihan piutang, memperketat syarat pemberian fasilitas piutang, melikuidasi persediaan, serta pelonggaran syarat untuk memperoleh kredit (Gracia, 2018:172). Lebih lanjut, Panda dan Nanda (2018:444) juga menjelaskan bahwa perusahaan dengan hambatan keuangan yang kecil dapat menggunakan sumber dana jangka pendek untuk membiayai modal kerjanya tanpa mempengaruhi profitabilitas perusahaan dan meminimalisir dampak negatif yang dapat timbul atas pembiayaan modal kerja yang menggunakan sumber dana jangka pendek.

Ukuran perusahaan dapat diukur atas aset-aset yang dimilikinya. Setiap perusahaan berupaya meningkatkan ukuran perusahaan untuk dapat memperoleh keunggulan kompetitif atas pesaing dengan mengurangi biaya produksi dan meningkatkan pangsa pasar (Olawale, Ilo, \& Lawal, 2017:2). Melalui peningkatan pangsa pasar, perusahaan dapat meningkatkan penjualan sehingga mencapai atau melebihi target yang telah ditentukan sebelumnya. Sehingga ukuran perusahaan memiliki pengaruh yang positif terhadap kinerja keuangan perusahaan. Pertumbuhan perusahaan atau Growth merupakan suatu ukuran yang menandakan bahwa tingkat perkembangan suatu perusahaan dari suatu periode tertentu ke periode berikutnya. Gracia (2018:174) menjelaskan bahwa perusahaan yang memiliki pertumbuhan yang tinggi dapat dipandang sebagai perusahaan yang memiliki prospek di masa yang akan mendatang, sehingga pihak kreditur dapat dengan percaya memberikan pinjaman kredit untuk mendukung kegiatan operasional perusahaan sehari-hari. Kelancaran kegiatan operasional perusahaan dapat mendukung kinerja perusahaan secara keseluruhan. Menurut Gitman dan Zutter (2015:560), Leverage dapat didefinisikan sebagai dampak dari pembiayaan yang dapat meningkatkan return bagi pemegang saham pada suatu perusahaan, dimana semakin tinggi pembiayaan maka akan semakin tinggi return yang diperoleh perusahaan dan risiko yang dihadapinya. Current Ratio merupakan sebuah pengukuran atas tingkat likuiditas perusahaan. Tingkat likuiditas suatu perusahaan yang tinggi menunjukkan bahwa perusahaan mampu memenuhi kewajiban jangka pendeknya dan membiayai kebutuhan tidak terduga. Perusahaan dengan tingkat likuiditas keuangan yang tinggi menunjukkan bahwa perusahaan mampu melaksanakan kegiatan operasionalnya dengan baik dan memberikan kinerja yang optimal.

\section{METODOLOGI PENELITIAN}

Penelitian ini dilakukan melalui pengujian secara kuantitatif atas bukti-bukti empiris berupa data keuangan dari sampel 40 perusahaan Consumer Goods dan 41 perusahaan Mining yang terpublikasi pada Bursa Efek Indonesia (BEI) selama tahun 2014 sampai dengan tahun 2018. Variabel dependen yang digunakan di dalam penelitian ini adalah Firm Performance. Sedangkan variabel independen digunakan di dalam penelitian ini adalah $W C F$. Terdapat variabel moderasi yang digunakan di dalam penelitian ini, yaitu Financial Constraints. Selain itu, penelitian ini juga menggunakan empat variabel kontrol yang meliputi Firm Size, Growth, Leverage, dan Current Ratio. Operasionalisasi variabel dapat diuraikan pada tabel berikut ini.

\section{Tabel 1}

Definisi Operasional Variabel

\begin{tabular}{|c|c|c|c|}
\hline Variabel & Ukuran/Indikator & Skala & Sumber \\
\hline \multicolumn{4}{|c|}{ Variabel Dependen } \\
\hline \multirow{2}{*}{$\begin{array}{l}\text { Kinerja Perusahaan } \\
\text { (Firm Performance) }\end{array}$} & ROA $=\frac{\text { Net } \text { Profit }}{\text { Total Assets }}$ & \multirow{2}{*}{ Rasio } & \multirow{2}{*}{$\begin{array}{c}\text { Altaf dan } \\
\text { Ahmad } \\
(2019: 469)\end{array}$} \\
\hline & $Q=\frac{\text { Market Value Equity }+B V \text { of Debt }}{B V \text { OF Assets }}$ & & \\
\hline \multicolumn{4}{|c|}{ Variabel Independen } \\
\hline
\end{tabular}




\begin{tabular}{|c|c|c|c|}
\hline $\begin{array}{c}\text { Pembiayaan Modal Kerja } \\
\text { (Working Capital } \\
\text { Financing) }\end{array}$ & WCF $=\frac{\text { Short Term Debt }}{\text { Current Asset-Current Liabilities }}$ & Rasio & $\begin{array}{l}\text { Altaf dan } \\
\text { Ahmad } \\
(2019: 469)\end{array}$ \\
\hline \multicolumn{4}{|c|}{ Variabel Moderasi } \\
\hline \multirow{3}{*}{$\begin{array}{c}\text { Kendala Keuangan } \\
\text { (Financial Constraints) }\end{array}$} & Size $=$ Ln $($ Total Asset $)$ & \multirow{3}{*}{ Rasio } & \multirow{3}{*}{$\begin{array}{l}\text { Altaf dan } \\
\text { Ahmad } \\
(2019: 469)\end{array}$} \\
\hline & Whited $W u$ Index* & & \\
\hline & Interest Coverage Ratio $=\frac{E B I T}{\text { Finance Expense }}$ & & \\
\hline \multicolumn{4}{|c|}{ Variabel Kontrol } \\
\hline Firm Size & Size $=$ Ln $($ Total Asset $)$ & \multirow{4}{*}{ Rasio } & \multirow{4}{*}{$\begin{array}{l}\text { Altaf dan } \\
\text { Ahmad } \\
(2019: 469)\end{array}$} \\
\hline Growth & Growth $=\frac{\text { Current } \text { Year Sales }}{\text { Previous Year Sales }}-1$ & & \\
\hline Leverage & Lev $=\frac{\text { Total Debt }}{\text { Total Assets }}$ & & \\
\hline Current Ratio & $C R=\frac{\text { Total Current Assets }}{\text { Total Current Liabilities }}$ & & \\
\hline
\end{tabular}

*Whited and Wu Index (2006) dihitung dengan rumus $=-0,091 \mathrm{CF}_{\mathrm{i}, \mathrm{t}}-0,062 \mathrm{DIVPOS} \mathrm{i}_{\mathrm{i}, \mathrm{t}}+0,021 \mathrm{TLTD}_{\mathrm{i}, \mathrm{t}}-$ $0,044 \mathrm{LNTA}_{\mathrm{i}, \mathrm{t}}+0,102 \mathrm{ISG}_{\mathrm{i}, \mathrm{t}}-0,035 \mathrm{SG}_{\mathrm{i}, \mathrm{t}}$, dimana:

$\mathrm{CF} \quad=\frac{\text { Cash Flow }}{\text { Total Assets }}$

DIVPOS = variabel dummy, bernilai 1 apabila perusahaan membayar dividen tunai dan

0 jika perusahaan tidak melakukan pembayaran dividen tunai.

TLTD $=\frac{\text { Long Term Debt }}{\text { Total Assets }}$

LNTA $=$ Ln (Total Assets)

ISG = Pertumbuhan penjualan industri perusahaan

SG $\quad=\frac{\text { Current Year Sales }}{\text { Previous Year Sales }}-1$

Variabel Financial Constraints menggunakan tiga proksi yang meliputi Firm Size, Whited and Wu Index, dan Interest Coverage Ratio yang bernilai 1 apabila nilai berada di atas nilai median sampel dan berlaku hal sebaliknya. Analisis statistik regresi di dalam penelitian ini menggunakan metode Generalized Method of Moments (GMM) untuk menghindari masalah endogenitas yang mungkin timbul (Altaf \& Ahmad, 2019:469). Terdapat tiga pengujian pada metode GMM yang meliputi Uji Sargan (J-statistik), Uji Arellano Bond (AR), dan pengujian hipotesis. Selain itu, akan dilakukan uji multikolinearitas sebagai salah satu bentuk dari uji asumsi klasik. Hipotesis statistik atas pengujian variabel dependen dengan menggunakan rasio $R O A$ dan Tobin's $Q$ dapat diuraikan sebagai berikut (Altaf dan Ahmad, 2019:468).

$R O A \mathrm{i}, \mathrm{t}=\beta_{0}+\beta_{1} W C F_{\mathrm{i}, \mathrm{t}}+\beta_{2} W C F_{\mathrm{i}, \mathrm{t}}^{2}+\beta_{3}$ Size $_{\mathrm{i}, \mathrm{t}}+\beta_{4}$ Growth $_{\mathrm{i}, \mathrm{t}}+\beta_{5} L e v_{\mathrm{i}, \mathrm{t}}+\beta_{6} C R_{\mathrm{i}, \mathrm{t}}+\gamma_{\mathrm{t}}+\delta_{\mathrm{i}}+\varepsilon_{\mathrm{i}, \mathrm{t}}$ $Q \mathrm{i}, \mathrm{t}=\beta_{0}+\beta_{1} W C F_{\mathrm{i}, \mathrm{t}}+\beta_{2} W C F^{2}{ }_{\mathrm{i}, \mathrm{t}}+\beta_{3}$ Size $_{\mathrm{i}, \mathrm{t}}+\beta_{4}$ Growth $_{\mathrm{i}, \mathrm{t}}+\beta_{5} L e v_{\mathrm{i}, \mathrm{t}}+\beta_{6} C R_{\mathrm{i}, \mathrm{t}}+\gamma_{\mathrm{t}}+\delta_{\mathrm{i}}+\varepsilon_{\mathrm{i}, \mathrm{t}}$

Lebih lanjut, hipotesis statistik atas pengujian variabel dependen menggunakan rasio ROA dan Tobin's $Q$ setelah memasukkan pengaruh dari variabel Financial Constraints dapat diuraikan sebagai berikut (Altaf dan Ahmad, 2019:472).

$R O A \mathrm{i}, \mathrm{t}=\beta_{0}+\left(\beta_{1}+\varphi_{1} D F C_{\mathrm{i}, \mathrm{t}}\right) W C F_{\mathrm{i}, \mathrm{t}}+\left(\beta_{2}+\varphi_{2} D F C_{\mathrm{i}, \mathrm{t}}\right) W C F_{\mathrm{i}, \mathrm{t}}+\beta_{3}$ Size $_{\mathrm{i}, \mathrm{t}}+\beta_{4}$ Growth $_{\mathrm{i}, \mathrm{t}}+\beta_{5}$ Lev $_{\mathrm{i}, \mathrm{t}}$ $+\beta_{6} C R_{\mathrm{i}, \mathrm{t}}+\gamma_{\mathrm{t}}+\delta_{\mathrm{i}}+\varepsilon_{\mathrm{i}, \mathrm{t}}$

$Q \mathrm{i}, \mathrm{t}=\beta_{0}+\left(\beta_{1}+\varphi_{1} D F C_{\mathrm{i}, \mathrm{t}}\right) W C F_{\mathrm{i}, \mathrm{t}}+\left(\beta_{2}+\varphi_{2} D F C_{\mathrm{i}, \mathrm{t}}\right) W C F_{\mathrm{i}, \mathrm{t}}^{2}+\beta_{3}$ Size $_{\mathrm{i}, \mathrm{t}}+\beta_{4}$ Growth $_{\mathrm{i}, \mathrm{t}}+\beta_{5} L e v_{\mathrm{i}, \mathrm{t}}+$ $\beta_{6} C R_{\mathrm{i}, \mathrm{t}}+\gamma_{\mathrm{t}}+\delta_{\mathrm{i}}+\varepsilon_{\mathrm{i}, \mathrm{t}}$

\section{HASIL DAN KESIMPULAN}

Hasil pengujian statistik deskriptif, multikolinearitas, Sargan, Arellano Bond, dan hipotesis sebelum dan setelah pengaruh dari Financial Constraints adalah sebagai berikut:

\section{Tabel 2}

Hasil Uji Multikolinearitas

\begin{tabular}{|c|c|c|c|c|c|c|c|c|c|c|}
\hline \multirow{2}{*}{ Variabel } & \multicolumn{4}{|c|}{ Perusahaan Consumer Goods } & \multicolumn{5}{c|}{ Perusahaan Mining } \\
\cline { 2 - 12 } & Mean & S.Dev. & Maks. & Min. & VIF & Mean & S.Dev. & Maks. & Min. & VIF \\
\hline$R O A$ & 0.103 & 0.126 & 0.719 & -0.427 & & 0,041 & 0,153 & 0,605 & $-0,644$ & \\
\hline$Q$ & 0.558 & 0.313 & 1,578 & 0.027 & & 0,295 & 0,175 & 0,872 & 0,004 & \\
\hline$W C F$ & 0.410 & 0.270 & 0.991 & 0.001 & 1,114 & 0,473 & 0,282 & 0,991 & 0,005 & 1,094 \\
\hline
\end{tabular}




\begin{tabular}{|c|r|r|r|r|r|r|r|r|r|r|}
\hline \multirow{2}{*}{ Variabel } & \multicolumn{9}{|c|}{ Perusahaan Consumer Goods } & \multicolumn{4}{c|}{ Perusahaan Mining } \\
\cline { 2 - 12 } & Mean & S.Dev. & \multicolumn{1}{|c|}{ Maks. } & \multicolumn{1}{c|}{ Min. } & \multicolumn{1}{c|}{ VIF } & \multicolumn{1}{c|}{ Mean } & S.Dev. & \multicolumn{1}{c|}{ Maks. } & \multicolumn{1}{c|}{ Min. } & VIF \\
\hline Size & 28.479 & 1.590 & 32.201 & 25.295 & 1,115 & 29,333 & 1,509 & 32,664 & 25,574 & 1,116 \\
\hline Growth & 0.199 & 1.734 & 24.185 & -0.746 & 1,013 & 0,577 & 3,931 & 42,725 & $-0,984$ & 1,033 \\
\hline Leverage & 0.459 & 0.317 & 2.900 & 0.039 & 1,046 & 0,523 & 0,270 & 1,898 & 0,041 & 1,118 \\
\hline CR & 2.335 & 2.613 & 28.490 & 0.252 & 1,099 & 5,611 & 8,058 & 55,791 & 0,001 & 1,044 \\
\hline
\end{tabular}

Dari 412able di atas dapat terlihat bahwa tidak terdapat multikolinearitas dalam penelitian.

\section{Tabel 3}

Hasil Uji Hipotesis

\begin{tabular}{|c|c|c|c|c|c|c|c|c|}
\hline \multirow{4}{*}{ Variabel } & \multicolumn{8}{|c|}{ Perusahaan Consumer Goods } \\
\hline & \multirow{2}{*}{\multicolumn{2}{|c|}{$\begin{array}{l}\text { Sebelum Pengaruh } \\
\text { Financial Constraints }\end{array}$}} & \multicolumn{6}{|c|}{ Setelah Pengaruh Financial Constraints } \\
\hline & & & \multicolumn{2}{|c|}{ Firm Size } & \multicolumn{2}{|c|}{ WWI } & \multicolumn{2}{|c|}{ ICR } \\
\hline & $R O A$ & $Q$ & $R O A$ & $Q$ & $R O A$ & $Q$ & $R O A$ & $Q$ \\
\hline$W C F$ & $0,163 *$ & $-0,082$ & $0,232 * *$ & $-0,501 * *$ & $-0,086 * *$ & $-0,114 * *$ & $0,247 *$ & $-0,290 *$ \\
\hline$W C F^{2}$ & $-0,197 *$ & 0,082 & $-0,319 *$ & $0,379 * *$ & $-0,141 * *$ & $0,018^{*}$ & $-0,284 * *$ & $0,365^{* *}$ \\
\hline WCFxDFC & & & $-0,199 * *$ & 0,619 ** & $0,136 * *$ & $0,187 * *$ & $-0,130$ ** & $0,321^{*}$ \\
\hline$W C F^{2} x D F C$ & & & $0,250^{*}$ & $-0,502 * *$ & $0,126^{* *}$ & $-0,023^{*}$ & $0,129 * *$ & $-0,427 * *$ \\
\hline Size & $-0,030$ & $0,172 * *$ & 0,002 & $0,172 * *$ & $-0,013$ & $0,150 * *$ & $-0,030$ & $0,167 * *$ \\
\hline Growth & $-0,002$ & $-0,001$ & 0,002 & 0,006 & $-0,001$ & $-0,004$ & $-0,002$ & $-0,001$ \\
\hline Leverage & $-0,184 *$ & -0 & $-0,162 *$ & -0 & $-0,1$ & 19 & $-0,183^{*}$ & $-0,050$ \\
\hline$C R$ & $0,005^{*}$ & $-0,005$ & $0,004 * *$ & $0,008 * * *$ & 0,0 & $-0,004$ & $0,004 *$ & $-0,005$ \\
\hline$m_{2}$ & 0,791 & 0,130 & 0,121 & 0,132 & 0,350 & 0,212 & 0,543 & 0,230 \\
\hline Sargan & 0,290 & 0,158 & 0,475 & 0,153 & 0,289 & 0,189 & 0,246 & 0,143 \\
\hline \multirow{4}{*}{ Variabel } & \multicolumn{8}{|c|}{ Perusahaan Mining } \\
\hline & \multirow{2}{*}{\multicolumn{2}{|c|}{$\begin{array}{l}\text { Sebelum Pengaruh } \\
\text { Financial Constraints }\end{array}$}} & \multicolumn{6}{|c|}{ Setelah Pengaruh Financial Constraints } \\
\hline & & & \multicolumn{2}{|c|}{ Firm Size } & \multicolumn{2}{|c|}{ WWI } & \multicolumn{2}{|c|}{ ICR } \\
\hline & ROA & $Q$ & $R O A$ & $Q$ & ROA & $Q$ & $R O A$ & $Q$ \\
\hline$W C F$ & $-0,335 * *$ & $-0,355^{* *}$ & $-0,030 * *$ & $-0,456 * *$ & $-0,210 * *$ & $-0,428 * *$ & $-0,070^{* *}$ & $-0,178^{* *}$ \\
\hline$W C F^{2}$ & $0,317 * *$ & $0,373 * *$ & $-0,030 * *$ & $0,444 * *$ & $-0,149 * *$ & $0,474 * *$ & $-0,118 * *$ & $0,217 * *$ \\
\hline WCFxDFC & & & $0,049 * *$ & $0,201 *$ & $0,209 * *$ & $0,120 * *$ & $0,212 * *$ & $0,217 * *$ \\
\hline$W C F^{2} x D F C$ & & & $0,019 * *$ & $-0,156^{*}$ & $0,137 * *$ & $-0,185 * *$ & $0,156^{* *}$ & $-0,197 * *$ \\
\hline Size & 0,008 & 0,008 & 0,002 & 0,023 & $-0,014$ & 0,005 & 0,017 & 0,008 \\
\hline Growth & $0,001 * *$ & 0,003 & $0,001 * *$ & & $0,001 * *$ & 0,003 & $0,001 * *$ & 0,003 \\
\hline Leverage & $-0,149 * *$ & 0,0 & $-0,154 * *$ & 0,059 & $-0,156^{* *}$ & 0,065 & $-0,124 * *$ & 0,095 \\
\hline$C R$ & $0,003 * *$ & $0,005^{* *}$ & $0,002 * *$ & $0,004 *$ & $0,002 * *$ & $0,005^{* *}$ & $0,002 * *$ & $0,004 * *$ \\
\hline$m_{2}$ & 0,101 & 0,113 & 0,092 & 0,106 & 0,085 & 0,102 & 0,109 & 0,070 \\
\hline Sargan & 0,338 & 0,316 & 0,377 & 0,318 & 0,392 & 0,313 & 0,368 & 0,346 \\
\hline
\end{tabular}

$*, * *, * * *$ masing-masing menunjukkan nilai signifikan pada taraf signifikansi $1 \%, 5 \%$, dan $10 \%$

Tabel sebelumnya menunjukkan bahwa model penelitian ini memenuhi Uji Sargan dan Uji Arellano Bond. Hasil pengujian hipotesis menunjukkan bahwa terdapat pengaruh positif dan non-linier atas Working Capital Financing (WCF) terhadap Firm Performance. Hal ini membuktikan bahwa kinerja keuangan perusahaan akan semakin meningkat sampai dengan batas tertentu ketika perusahaan menggunakan proporsi kewajiban jangka pendek yang lebih besar untuk membiayai kebutuhan modal kerja di dalam perusahaan (manfaat yang diperoleh perusahaan akan lebih besar jika dibandingkan dengan biaya yang dikeluarkannya untuk memperoleh sumber pendanaan). Pengujian hipotesis juga menunjukkan bahwa terdapat pengaruh signifikan dari Financial Constraints terhadap hubungan positif dan non-linear antara Working Capital Financing (WCF) dengan Firm Performance. Hal ini membuktikan bahwa perusahaan yang kurang mengalami hambatan keuangan untuk memperoleh sumber pendanaan dapat menggunakan proporsi kewajiban jangka panjang atau utang lancar yang lebih besar tanpa mengurangi profitabilitas ataupun kinerja keuangan perusahaan. Hal ini disebabkan karena perusahaan yang kurang mengalami hambatan keuangan dapat memperoleh sumber pendanaan dengan tingkat bunga yang lebih rendah sehingga dapat memberikan manfaat bagi perusahaan untuk meningkatkan kinerja keuangan perusahaan. 


\section{SARAN}

Penelitian yang dilakukan ini masih memiliki banyak keterbatasan. Penelitian selanjutnya dapat dilakukan tidak hanya pada perusahaan manufaktur, namun dapat diperluas pada sektor lainnya. Penelitian selanjutnya juga dapat dilakukan dengan memperpanjang periode penelitian. Perkembangan sektor ekonomi, politik, dan sosial pada tahun-tahun mendatang dapat menyebabkan kebijakan pembiayaan modal kerja yang berbeda pula bagi perusahaan. Selain itu, penelitian selanjutnya dapat dilakukan dengan menambahkan variabelvariabel lain terkait kebijakan pembiayaan modal kerja di dalam suatu perusahaan.

\section{DAFTAR PUSTAKA}

Altaf, N., \& Ahmad, F. (2019). Working capital financing, firm performance and financial constraints: Empirical evidence from India. International Journal of Managerial Finance, 15(4), 464-477.

Baños Caballero, S., García Teruel, P. J., \& Martínez Solano, P. (2016). Financing of working capital requirement, financial flexibility and SME performance. Journal of Business Economics and Management, 17(6), 1189-1204.

Bereznicka, J. K. (2014). Capital structure as a determinant of working capital management: Empirical evidence across size groups of firms in the Eu countries. Journal of International Scientific Publications, 8(1), 36-54.

Ding, S., Guariglia, A., \& Knight, J. (2013). Investment and financing constraints in China: Does working capital management make a difference. Journal of Banking \& Finance, 37, 1490-1507.

Gitman, L. J., \& Zutter, C. J. (2015). Principles of Managerial Finance: Global Edition (14 ed.). Essex: Pearson Education Limited.

Gracia, E. (2018). Working capital, financial constraints, and firm value: Evidence of Indonesia manufacturing firms. Journal of Economics and Business, 1(2), 171-176.

Luqman, O., Ilo, B. M., \& Lawal, F. K. (2017). The effect of firm size on performance of firms in Nigeria. The IEB International Journal of Finance, 15, 2-21.

Panda, A. K., \& Nanda, S. (2018). Working capital financing and corporate profitability of Indian manufacturing firms. Management Decision, 56(2), 441-457.

Yudiaatmaja, F. (2013). Analisis Regresi dengan Menggunakan Aplikasi Komputer Statistik. Jakarta: PT Gramedia Pustaka Utama. 